\title{
Exploiting Religion for Wealth Generation in Yorubaland of Nigeria: The How and Why
}

\author{
Mustapha, Adejoro Raheem, ${ }^{1, *}$ \\ ${ }^{1}$ School of Arts and Social Sciences, National Open University of Nigeria, 14/16 Ahmadu Bello Way, Victoria Island, \\ Lagos, Nigeria \\ *Correspondence: School of Arts and Social Sciences, National Open University of Nigeria, 14/16 Ahmadu Bello \\ Way, Victoria Island, Lagos, Nigeria. Tel: 234-703-233-3494. E-mail: raheemmustapha@yahoo.com
}

Received: January 19, 2016

Accepted: January 25, 2016

Online Published: January 31, 2016

doi:10.5430/wjss.v3n1p33

URL: http://dx.doi.org/10.5430/wjss.v3n1p33

\begin{abstract}
Discussions in this paper are based on socio-religious cum philosophical views of such scholars as Emile Durkheim, Max Weber, Sigmund Freud and most especially Karl Marx who views religion as 'opium of the people'. This explains why some people in Yorubaland of Nigeria hide under the practice of religion to enrich themselves at the expense of other people. Using historical and descriptive methods, the paper investigated and found out that, as a result of high level of unemployment rate, greed and laziness, many people in the study area have taken the practice of religion as the quickest way of amassing wealth for themselves using crooked means, and this negatively affects the socio-economic status of Yorubaland in particular and Nigeria as a nation. The paper recommended employment generation, religious education, and checks and balances as corrective measures.
\end{abstract}

Keywords: religion, wealth-generation, yorubaland, miracle, dream, vision, Tahajjud, vigil, father-christmas, Mawlidun-Nabiyyi

\section{Introduction}

Life is full of ups and downs. Nature itself is dynamic and not static. Seasons naturally are of dry and wet. All of these allude to the fact that human beings are not created to be equal both in physical strength and in providence. Some people are seen living in affluence while some are seen wallowing in abject misery and precarious condition. Life has been so unpredictable that the affluent are sometimes found entangled in the turbulent water of insecurity, poor health condition and fear. In an attempt to get out of the flame of terrestrial 'hell', many people seek refuge in those believed to be custodians of celestial haven, that is, 'the men of God' who always call out to the troubled to bring their burdens and problems to their fortress. Among the Yoruba people, men of God are considered to be like salt which is used to preserve iru (a kind of local condiment produced from locust bean, used as delicacy to prepare food) from being decay. But alas! the 'salt' (men of God) now appear to be decaying and the question now is that with what are they to be preserved? These people turn out to be unsuspected 'hyenas' hunting the 'sheep' grazing under them. In other words, a cluster of "Men of God" in Yorubaland of Nigeria, through crooked means, take advantage of religion to create wealth under the pretext of providing spiritual guidance, healing and solutions to people's predicaments.

Nigeria, particularly in the South Western area, has, in recent time, turned out to be the modern Israel where people are being called to prophet-hood almost on daily basis. This is evident in the proliferation of religious houses springing up at every nook and cranny where people visit for spiritual therapy. It is worth noting that the people in this area of research practice different religions. However, our attention in this paper is focused on Christianity and Islam which are predominantly professed. Buildings, shops and stores which had hitherto been utilized for one commercial activity or the other, are being bought over or hired to be converted into religious houses. Walls of private houses, bus stops and other public places are being defaced with posters carrying pictures of 'men of God'. Many bill boards that were erected originally for advertisement of industrial products and new other ones, are now conspicuously displaying the beautiful photos of General Overseers, Pastors (either male or female), Evangelists and Sheikhs. To cap it up are paid advertisements on Radio and Television, sponsored by various individuals, religious 
bodies and denominations, which have become a major source of income generation for the media houses. The outcome of this is that many people are always found busy clapping, singing and dancing in religious houses especially in churches at the time they ought to engage in some economic activities that would have contributed to their personal economic growth and that of the nation. The present religious outlook in Nigeria to which the Yoruba-land is a part, has best been described by Mbewe (2011) in the following quotation:

...by "Nigerian religious junk" I mean the phenomenon of churches that are personal-to-holder... It does not matter which country you go to, the bill boards of these churches do not have the faces of the local pastors of the congregations in those towns but of the founding father in Nigeria - or wherever he has since relocated. It is all about image and power. This "man of God" claims to hear the voice of God and proceeds to minister to you accordingly. If you do not obey him you are resisting the ministry of God into your life. So, the churches are often called "ministries" rather than churches.

It is in the light of this that this paper discusses how and why many people allow some others to wittingly and cunningly take advantage of their misfortune to enrich themselves only in the name of God, thereby justifying Marx's view that religion is opium of the people (Marx 1970).

\subsection{Yoruba-land and its People}

Yoruba-land forms one of the six geo-political zones of Nigeria. It constitutes six out of the 36 States in the country. The six States are Ekiti, Lagos, Ogun, Ondo, Osun and Oyo. Yoruba people also constitute a sizable proportion of Kwara, Kogi and Edo States while some permanently reside in communities such as Sabe, Ketu and Dassa all in the neighbouring Republic of Benin. According to the 2006 census figures in Nigeria as published by the Nigeria MasterWeb (2006), Yoruba-land has 27,511,992 inhabitants making it the second largest populated zone after the North West which has a total of 35,786,944 inhabitants. Yorubaland is an area naturally blessed with vast arable land. This accounted for the fame and success recorded by the pre-independence government of the region under the premiership of Obafemi Awolowo which made a great fortune from agriculture between 1954 and 1960. Traditionally, the Yoruba, as people in the sub-region are known, are farmers. They grow food and cash crops like yam, beans, cassava, plantain, cocoa, kolanut, rubber, coffee, and etcetera. Only a little percentage of the people is employed as merchants, craft-men or artists. The Yoruba people are socially receptive and highly dedicated to whatever they believe in (Come to Nigeria 2010)).

\subsection{Religion among the Yoruba People}

There are divergent opinions on whether or not religion has a common form of definition. For example Smith (1982) sees religion as nothing but 'a staggering amount of data, phenomena, of human experiences and expressions that might be characterized in one culture or another, by one criterion or another, created solely by scholar's study'. Houghton Mifflin Company (2002) defines religion as, among others, "belief in, worship of, or obedience to a supernatural power or powers considered to be divine or to have control of human destiny" and to Hornby (2005) religion is 'one of the systems of faith that are based on the belief in the existence of a particular god or gods'. Albeit, there are some people who do not see any need for religion to exist. Representing this group is Sigmund Freud who, as stated by McGrath, opined that religion is an illusion propelled by man's instinctual desires (McGrath 1999). This is in averse to Durkheim who sees religion as the glue that held society together (Durkheim 1915).

As a means through which man communicates with gods/God, the Yoruba people of South West Nigeria attach much importance to religion. Prior to the advent of Islam and Christianity in the area, people were engrossed in the practice of African Traditional Religion which afforded the opportunity to worship various deities such as Ogun, Obatala, Sango, Egungun, Osun and many others. Each of these deities had priests whom people trusted and had confidence in. These priests were the intermediaries between the deities and the worshippers. They consulted the deities on behalf of the worshippers and communicated the deities' messages to the people with sincerity and truthfulness. It was believed that any priest that failed to be truthful was bound to face the wrath of the gods. Therefore, both the worshippers and the priests were very conscious of what they would do and what they would say. Nothing, including money would ever make the priests and the worshippers exploit or defraud. People were so truthful that traders would confidently leave their merchandise outdoor and put a number of pebbles to indicate the amount with which they wanted to sell those items and interested buyers would drop money equivalent to items bought which the seller would meet intact. 
With the advent of Islam in the area in the late eighteenth century and Christianity within the first half of the nineteenth century (Ikimi 1980, 347-349), many people jettisoned the African Traditional Religion to embrace either of the two new religions. The early people who embraced and practiced these religions did that with all sincerity. People related with one another with the fear of God who, though could not be seen physically, was believed to have ability to see and can seize as He wishes. In spite of people's devotion to religious practices, they were known to be highly hard-working and industrious. Farmers, traders, artisans and craft-men among them engaged in their businesses carrying their religious consciousness with them. The chief concern of the two religions has been the welfare of their members; however the services which the religions rendered to the people, according to Ikimi (1980, 363), have had a direct or cumulative effect on the society. These religions facilitated positive transformation in the lives of the believers on one hand and also added new dimensions to the cultural heritage of the country by introducing a new form of education and culture. The religions taught moral values and emphasized the necessity for upholding such values. Religious leaders then led by examples. Little attention was paid to worldly riches while much emphasis was laid on eschatology and on how to win the kingdom of God. No wonder then that people of religion were considered trusted confidants within the society and people visited them with their barrage of problems. Prayers were offered with sincerity without conditional material attachment. Those whose problems were thus solved willingly offered money or materials as appreciations majorly for the promotion of religion. However, the religious situation at present in Yoruba-land calls for serious concern and rethink. Day-by-day, there are reports of fraudulent activities being traced to churches or mosques. Magnificent churches and mosques are springing up everywhere in big cities while religious leaders are in the forefront on the lists of the bourgeoisies in the society at the expense of their poor 'herds' who are being 'milked' to bones at all times. The social and humanitarian services which the religious bodies of the past were known for are fast giving way to business ventures of the present time especially by churches. The missionaries of the old Anglican Church, the Methodist Church, the Catholic Church, the Ansār-ud-Deen Society, the Ahmadiyyah, and etcetera, who struggled hard to establish schools and to build hospitals, did that on humanitarian ground to give education and health-care to the common men, free of charge. The missions did not measure their successes and achievements by the size and beauty of their church buildings or by the affluence of their leaders. Rather, their target and concern were how to improve on the lives of their members and those of the indigents in the society. Today, things have changed as many people now hide under religion to defraud others. Why and how this is done is the next focus in this discussion.

\subsection{The Get-rich-quick Syndrome}

A common saying says 'poverty is a disease'. Nigeria is a nation blessed with abundant human and material resources but ridden with poverty and insecurity. Unemployment rate is at a high level. Worse still, those who could have been self-employed using their god-given intelligence and expertise are incapacitated by lack of social infrastructures such as electricity and good road network which could have made their efforts fruitful. Many school leavers have thus turned scavengers and corporate beggars while some have chosen to engage in criminal and shameful activities such as armed robbery, drug peddling and prostitution in order to make ends meet. Be this as it may, the few opportunists who were entrusted with political powers arrogate such powers to themselves as they squander the commonwealth of the people with utmost impunity. It is possible for a semi-literate politician who was nobody yesterday to become a wealthy and celebrated man today having fleet of cars and a large number of houses under his control just because he is elected or selected to occupy a political position. As of today in Nigeria, running of religious houses are considered "a vastly profitable venture" where Pastors are seen "moving from a live of average financial status to stupendous wealth in a matter of months" (Nairaland Forum, 2013). As a result of this, an average Nigerian, especially the young ones, go crazy in search of ways of becoming wealthy at all costs. Hence, many of them choose to achieve this through religious means by claiming to have been called upon by God for evangelism. This situation in Nigeria is best described by Temionu $(2015$, p.34) in the following quotation:

In the country today, poverty, uncertainty, corruption and nepotism have made many Nigerians become strong believers in getting all categories of problems solved through some metaphysical means. And many religious houses and some clergymen appear to be taking advantage of that to milk their victims.

\section{Modus Operandi of the 'Men of God'}

\subsection{Miracles and Wonders}

Like Durkheim's theory of totemism in which clans are symbolized by objects of worship, what can be described as miracleism (miracle-based religiosity) is now the order of the day in the religious arena of the South-Western Nigeria 
where working miracles in the name of God has become the logo for the presence of God which invariably turns out to become a short-cut to riches. Many people do not go to religious houses for the purpose of worship but to receive miracles and wonders. Thus many unemployed University and college graduates have turned founders, Pastors and General overseers of various religious organizations and churches from where they make their fortunes by working 'miracles'. There are people who choose to abandon their jobs for setting up churches which are being superintended by their immediate families only, while some who retain their jobs, as a matter of greediness, take them as subsidiaries to the running of their churches or religious organizations. Nigeria is a nation that is bedeviled with numerous socio-economic problems; hence, quest for miracles and wonders to get them solved has led many people into falling victims of fraud from the hands of many "cash-and-carry men and women of God" whose interest is not to win souls for God, but how to boost their bank account and prestige (Anele 2014). In Yoruba-land, especially in cities such as Lagos, Abeokuta, Ibadan, Oshogbo, Akure, Ondo, Ogbomosho, Ijebu, Ilesha, and Ado-Ekiti, to mention but just a few, miracles and wonders are always the themes of many religious programmes being organized on daily basis. As Christians organize night vigils, Muslims organize Tahajjud, which were purportedly to solve either temporal or spiritual problems of the people and at the end of which offerings are demanded. It should be stated here that the concern of this paper is not whether or not such organized programmes are legitimate, but why money and materials are raised in such programmes and how such proceeds are utilized. Most often, it appears as if the intention for organizing programmes is not for the benefits of the ordinary members of the religious groups but for the use of the organizers and their spiritual fathers or mothers. This is seen in the trend in which the religious leaders accumulate wealth and live bogus life at the expense of unsuspecting 'sheep'. The mode of operation of these 'religious men and women' include 'prosperity gospel', 'dreaming and seeing visions', 'organizing vigils or Tahajjud', 'celebrations of Father Christmas' and 'Mawlidu n-Nabiyyi', among others. Some of the aforementioned are alien ideas and practices introduced into religion thereby justifying the Freud's position as cited by McGrath $(1999,178-181)$ that the whole idea of religion is an illusion.

\subsection{Prosperity Gospel}

Phrases and sentences such as 'sowing of seed' and 'give to Caesar what is Caesar's and give to God what is God's' are in vogue in many churches of today. These statements are nothing but calling on worshippers to part with their money or other materials in expectation of multiple replacement by God. Little is said about salvation through righteousness and repentance any longer. The main theme of sermons in many religious gatherings nowadays is prosperity and deliverance from the shackles of enemies through miracles. The congregations are made to believe that poverty is a sin and that God has not created man to be poor. Hence, people are called upon to bring all their problems to the house of God for spiritual solutions. The larger part of service hours is on thanksgiving and giving testimonies which are anchored on offerings. When programmes like wedding, funeral, or any other celebration are organized in some religious houses, request envelop is always tucked in the programme booklet in which everyone present is expected to put some money. Some religious houses hire the services of bank officials to take charge of proceeds of every service session. At the end, it is the 'men of God' that have the larger part of the wealth so gathered. It is on record today that many Nigerian 'men of God' make the list of the group of richest personalities in the country. One may be in doubt if too much inclination to riches would not have adverse effect on religiosity. This scenario had once happened in France and Germany as posited by Weber (2001, 51-52). Some of them have private jets, estates of building and acres of land in strategic locations, big investments, and handsome money deposit in bank accounts. This scenario was described by Madukovich (2013) in the following way:

.... at the top of hierarchy as the holiest of all is the 'pastor', who must then prove his holiness and height of righteousness by amassing so much wealth at least beyond that of most of his parishioners...This has led to the justification of several crimes and financial indiscretions, as long as part of the proceeds are paid in tithes...

No wonder then that many religious houses, especially in South-Western Nigeria, are crises-ridden as members always fight over leadership control.

\subsection{Dream and Vision}

Dream is an experience which someone goes through during sleep. It is said to be the reason behind God's placing sleep in the animate world so that "everyone might ... know that there is another world similar to the sensory world." (Chittick, 1989, 119). In the world of dream-imagination according to Chittick, "the mysteries of God and his creation, otherwise impenetrable to the human intellect and sense perceptions, are unveiled."

Dreaming and seeing visions are parts of the antics of some of the so-called men and women of God. The former (dreaming) is common among young Muslim clerics called Alfa (scholar) some of whom arrogate the title of Sheikh 
(which, in the context of this paper, is an Islamic title for an old but pious scholar) to themselves while the latter (vision) is a common phenomenon in the church. In traditional Islam, the major responsibility of any Alfa is to teach and preach the Islamic virtues and scriptures to people. But nowadays an average 'Alfa', especially in our area of study in this research, practices jalabi (spiritual and medical services) in which they mostly engage in fetishism, divination and fortune-telling as means of livelihood. They are found mostly in urban centers where they can easily get 'customers'. Many of their claims and practices which include dreaming are to deceive their gullible clients in order to dupe them of their belongings. By so doing, many of them are seen riding in luxurious cars, marrying wives and living ostentatious lives.

"Evangelism" inside public buses in cities such as Lagos is a common practice. This researcher was an eye witness to a 'Pastor' whose theme of sermon on that particular day was 'efficacy of prayers'. He claimed that God, through a vision, had asked him to inform the passengers to offer a prayer at a particular hour of the day and that by that hour of the following day, they would see wonders from God. At the end of his sermon, he said God had chosen fourteen (14) among the passengers in the bus 3 of whom should donate one thousand Naira each while the remaining 11 should donate one hundred Naira each, with the promise that by so doing, God would compensate each of them with one hundred and seventy thousand (N170,000) Naira the following day. It was amazing to see Nigerians in the bus rushing to the man to donate money who had played upon their gullibility.

\subsection{Vigils and Tahajjud}

'Vigil' to Christians or Tahajjud to Muslims refers to a period of time especially at night when people are awake for the purpose of worship and seeking of spiritual uplift. It is an exercise through which the doors of the sky are opened to worshippers and their supplications answered as a result of voluntary worship and prayer and closeness to God (Muslim Forum 2012). To keep vigil is a religious practice with scriptural backing from both Islam and Christianity. For instance scriptural evidences relevant to keeping vigil are contained in Q17: 78-79, Q32:16-17 and Exodus 12:42.

The above scriptural references show the purpose for which night vigil should be observed. That is for the service and worship of God alone. However, the night vigil as observed by religious people and their leaders in most part of Yoruba-land is characterized by collection of offerings attached to prayer points. For each prayer point, worshippers are often requested to donate money as if it is the money that will answer their prayers. In this way, many "men and women of God" especially the sole founders of the religious houses or organizations, have amassed a lot of wealth for themselves at the expense of many unsuspecting less-privileged worshippers.

\subsection{Father Christmas}

The celebration of Father Christmas which is alien to early Christians has finally found its way into Christianity especially in the Yoruba-land of Nigeria. It has become a household affair as each Church, school, media house, and family, organizes the event on yearly basis mostly to generate money. It is often branded as being part of religious rites in which a make-believe Father Christmas is presented to people especially little children who are always made to believe that the Father Christmas is from Rome or Jerusalem. The organizers' claim of organizing the programme to make the little children happy at Christmas is contradicted by the introduction of gate-fee from which they (the organizers) make huge amount of gains.

\subsection{Mawlidu n-Nabiyy}

Mawlidu n-Nabiyy is the celebration of the birth of Prophet Muhammad by the Muslims. This celebration which has no basis in Islam has also found its feet deeply rooted among the Yoruba Muslims. The Prophet was claimed to have been born on the twelfth of Rabi' 'ul Awwal which is the third month of the lunar calendar in the year 570 C.E. However, the celebration of his birthday takes months in Yoruba-land. Throughout the month of Rabi 'ul Awwal and up till the end of Sha 'abān which is the eighth month of the lunar calendar, different Islamic organizations, mosques, madāris (Arabic and Islamic schools), and individuals organize Mawlidu n-Nabiyy which is well publicized in both print and electronic media. Letters of invitations are sent out to eminent personalities in the society. At the occasion of such celebrations, invited politicians and business moguls always prove their worth by donating money for 'propagation of religion'. Envelops are distributed by organizers to solicit monetary donations from other members of the public. Most often on the day of celebration, events such as singing and drama-staging are organized to entertain audience while little attention is paid to lessons that can be derived from the life of Prophet Muhammad and the need to keep his way of life (sunnah). Proceeds from such occasions are taken care of by the organizers mostly for their domestic upkeep. 


\section{The Effects of Abuse of Religion on Socio-Economic Growth of Nigeria}

\subsection{Insecurity in Religious Houses}

Religion is supposed to be a source of comfort to people. The men or women of God are supposed to be models and epitomes of virtue in the society. However, the activities of some men and women of God especially in Yoruba-land of Nigeria create fear and doubt in the mind of right-thinking people. Many have turned religion to business enterprise in order to generate income. In the cause of doing so, many have lost credibility as a result of their insincerity and intellectual misdemeanor (Freud 1928, 77). No wonder then that sometimes, religious houses surfer armed-robbery attacks during which huge sum of money are stolen. There were reports on a particular Christ Apostolic Church (CAC) in Alagbado area of Lagos, attacked by armed robbers during a vigil session during which the offering of about two million (2m) Naira and some other valuables were carted away (Kemifilani 2014). For a religious house to have generated such a huge amount of money in a night of vigil which ordinarily should have been dedicated exclusively for religious exercises is a pointer to the fact that some religious leaders have turned religion into money-making business. Hence religious houses become a point of attraction to armed robbers.

\subsection{Fight and Division in the Houses of God}

Struggle for control of religious houses among groups is a popular occurrence in Nigeria particularly in Yoruba-land. The cause of factional crises is not unconnected with the issue of leadership tussle, resource control and sharing of proceeds (Filani 2014). The case of a clash in a Cherubim and Seraphim (C\&S) Church in Kogi State of Nigeria is a good example here where the children of the late founder of the Church (which had branches in the United Kingdom and the United States) engaged in a bloody clash with the new General Overseer of the church in an attempt to take over the control of the Church which was believed to be their father's property (CityNews 2015).

\subsection{Distraction from More Economically Viable Job}

Many youths who could have been more productive in other sectors of the economy now prefer to set up churches where they make themselves Pastors. Many of these Pastors, who are overzealous and desperate to get rich quick, engage in fetishism to attract worshippers who would be the 'money spinning machines' for the church. This is a situation not peculiar to one religion. Muslim and Christian clerics do promise their congregations worldly riches and terrestrial successes through prayers and miracles which according to Isa (2011) is at monetary costs.

\section{Recommendation}

It has been revealed in this paper how some people use religion to make money for themselves in Yoruba-land of Nigeria in particular. The paper has also laid bare the negative effects which such a practice has on the socio-economic development of the people. In an attempt to ameliorate the situation, the following suggestions are made:

i. All hands must be on deck to reduce the unemployment level in the country. Many higher school leavers choose to become 'men and women of God' as an alternative to their preferred jobs which are not easily come by. Many of the so-called men and women of God could be more productive in agricultural production if they have been encouraged to do so.

ii. Nigerians need to be properly tutored about religion. God, being the Creator of all, is approachable to all at any time and at any point. Rather than running after miracles and wonders, people should be made to know that no intermediary is needed between them and their Creator for their prayers to be answered and for their sins to be forgiven.

iii. Religious leaders should put up mechanisms to control the excesses of their members who are fond of using religion to amass wealth. They should also lead by examples and avoid ostentatious life. Their life-style should serve as model for others. A situation as we have it in Nigeria whereby ownership of private jets, estates, cars, factories, private educational institutions, and etcetera becomes a competition among religious leaders, sends bad signals to others who may want to emulate them in their ways of life.

\section{Conclusion}

The abuse of religion for selfish gains in the Nigerian society is not peculiar to individuals alone. At the government level, many officials also hide under the sponsorship of religious programmes and pilgrimages to enrich themselves and their cronies (Liman 2012). As it has been revealed in this paper, the practices of some people who use religion to take advantage of the unfortunate situation of other people in the study area in order to enrich themselves, defeat 
the whole essence of religion which, in Emile Durkheim's view, "is to give meaning to man's existential predicaments" (Coser 1977, 136-139).

\section{References}

Anele, Douglas. (2014). "How religion underdeveloped Nigeria (3)" Vanguard, January 05. Retrieved from http://www.vanguardngr.com/2014/01/religion-underdeveloped-nigeria-\#disqus_thread

Chittick, William. (1989). The Sufi Path of Knowledge: Ibn al- 'Arabi's Metaphysics of Imagination. Albany: SUNY Press.

CityNews. (2015). Bloody Fight Breaks Out In Cherubin \& Seraphim Church. Retrieved from http://citynews.ng/bloody-fight-breaks-out-in-cherubin-seraphim church/\#sthash.qmqxRqKS.dpuf

Come to Nigeria. (2010). "Yoruba People" In: Come to Nigeria. Retrieved from http://www.cometonigeria.com/about-nigeria/nigerian-people-culture/yoruba-people/

Coser, Lewis A. (1977). Masters of Sociological Thought: Ideas in historical and social context. New York: Harcourt Brace Jovanovich. Inc.

Durkheim, E. (1915). The Elementary Forms of the Religious Life. London: George Allen \& Unwin Ltd.

Filani, S'ola. (2014). “'He stopped sleeping at home...': Revelation from pastor's wife tears church apart, husband fights dirty" Retrieved from http://www.ynaija.com/he-stopped-sleeping-at-home-revelation-from-pastors-wife-tears-church-apart-husband-f ights-dirty-pictured/

Hornby, A.S. (2005). Oxford Advanced Learner's Dictionary of Current English. Oxford: Oxford University Press.

Houghton Mifflin Company (2002). The American Heritage Idioms Dictionary n.p. Houghton Mifflin Company.

Ikimi, Obaro. (1980). Groundwork of Nigerian History. Ibadan: Heinemann Educational Books (Nigeria) Limited.

Isa, M. Q. Sidq. (2011). Explaining the Irony of Nigerians' Religiosity and their corruption Notoriety. Retrieved from $\mathrm{http} / / / \mathrm{www}$.nigeriavillagesquare.com/articles/guestarticles/explaining-the-irony-of-nigerians-religiosity-and-thei r-corruption-notoriety.html

Kemifilani. (2014). Another Church Robbery! Armed robbers attack CAC church during vigil. Retrieved from http://www.kemifilani.com/2014/03/another-church-robbery-armed-robbers.html

Liman, Bala Mohammed. (2012). Religion and State Abuse in Nigeria. NIGERIA INTEL, Retrieved from http://www.nigeriaintel.com/2012/08/23/religion-and-state-abuse-in-nigeria/

Madukovich, M. (2013). Salvation and the gospel of prosperity. Retrieved from http://madukovich.wordpress.com

Marx, Karl. (1970). Introduction to A Contribution to the Critique of Hegel's Philosophy of Right. Joseph O'Malley (Trans.) Oxford University Press. Retrieved from http://www.marxists.org/archive/marx/works/

Mbewe Conrad (2011, February 20). "A Letter from Kabwata" Retrieved from http://www.conradmbewe.com/2011/02/nigerian-religious-junk.html

McGrath, Alister E. (1999). Chapter 23: The Psychology of Religion. Science \& Religion: An Introduction. Oxford, UK: Blackwell. Retrieved from https://sites.google.com/site/psychologyandreligion/home/sigmund-freud-s-theories-and-criticisms-of-religion

Muslim Forum (2014). The Virtues of praying Tahajjud - The Night Vigil prayer. Retrieved from http://www.123muslim.com/islamic-articles/18328-virtues-praying-tahajjud-night-vigil-prayer.html

Nairaland Forum "Nigeria's Five Richest Pastors And How They Made Their Wealth" Nairaland Forum Blog 2013. Retrieved December 22, 2015, from http://www.nairaland.com/1216755/nigerias-five-richest-pastors-how\#up

Nigeria 2006 Census Figures. Retrieved from http://www.nigeriamasterweb.com/Nigeria06CensusFigs.html

Smith Jonathan Z. (1982). Imagining Religion: From Babylon to Jonestown. Chicago: The University of Chicago Press.

Tunde Temionu. (2015). Between religion and political soothsaying. The PUNCH, January 28.

Weber, Max. (2001). The Protestant Ethic and the Spirit of Capitalism. Talcott Parsons (Trans) London and New York: Routledge Classics. 